\title{
El Coeficiente de Pulimento Acelerado y su relación con parámetros petrográficos (contraste de dureza y composición modal) y la microrrugosidad superficial de áridos naturales y artificiales
}

\section{Polished Stone Value Test and its relationship with petrographic parameters (hardness contrast and modal composition) and surface micro-roughness in natural and artificial aggregates}

\author{
$\underline{\text { A. Fernández }}^{(*)}$, M. A. Alonso(**), F. J. López-Moro(*), M. C. Moro(*)
}

Recepción / Received: 30-III-2012

Aceptación / Accepted: 21-IX-2012

Publicado online / Online publishing: 22-IV-13

\section{RESUMEN}

El objetivo de este trabajo es establecer, por un lado, las relaciones existentes del CPA con las características petrográficas de los áridos, así como su microrrugosidad superficial y, por otro, las diferencias de comportamiento entre áridos naturales y artificiales. Los resultados indican que en los áridos naturales la microrrugosidad superficial y el diferente valor del CPA están determinados, en gran medida, por las diferencias de dureza de sus minerales y también por la proporción en la que estos minerales se encuentran en las distintas litologías. Sin embargo, en los áridos artificiales (escorias de fundición) su elevada porosidad es la responsable de su marcada microrrugosidad superficial y su elevado valor del CPA. Finalmente, se relaciona el CPA con un parámetro petrográfico (Contraste de Dureza Global, $\Delta \mathrm{H}$ ) mediante una curva exponencial, cuyo excelente índice de regresión hace que sea factible estimar mediante el estudio petrográfico de un árido su valor del CPA (CPA $\left.=39,726 \Delta \mathrm{H}^{0,057}\right)$.

Palabras clave: áridos; capa de rodadura; coeficiente de pulimento acelerado; propiedades mecánicas y físicas.

\section{ABSTRACT}

The goal of this work was first to establish the relationships between the PSV values and the microstructural and mineralogical features of the aggregates and surface micro-roughness, and then to establish the behavioural differences between natural and artificial aggregates. The results obtained indicate that the surface micro-roughness and the different PSV values of the natural aggregates are strongly governed by the existence of minerals with different degrees of hardness, together with the proportion of these minerals. In contrast, the different degree of porosity in artificial aggregates (a furnace slag) was seen to be responsible for its high surface micro-roughness and PSV values. Finally, the PSV and a petrographic parameter (Overall Hardness Contrast, $\triangle H$ ) were seen to be related by an exponential curve ( $P S V=39.726 \Delta H^{0.057}$ ) with an extremely good fit, providing a good tool to estimate PSVs in natural and artificial aggregates from petrographic parameters.

Keywords: aggregates; wearing course; polished stone value; mechanical and physical properties.

(*) Universidad de Salamanca (Salamanca, España).

(**) PAS Infraestructuras y Servicios S.L. (Salamanca, España). 


\section{INTRODUCCIÓN}

En las carreteras, la capa de rodadura contribuye y condiciona, de forma decisiva, la respuesta del pavimento ante las exigencias de seguridad, comodidad, resistencia e impermeabilidad. Así, en el primer caso, la capa de rodadura debe tener buenas propiedades antiderrapantes, que son dependientes de la textura superficial y de un factor de rugosidad mínimo exigible. En este sentido, en las mezclas bituminosas utilizadas para capas de rodadura hay que considerar las propiedades de los áridos que proporcionen unos niveles adecuados de adherencia neumático-carretera. Entre las características petrográficas, la mineralogía y microestructura son factores determinantes (1-4). Algunos trabajos han tratado de comparar los resultados de ensayos tecnológicos (coeficiente de pulimento acelerado -CPA-), con la microtextura $(5,6)$ y la petrografía de los áridos (7), pero son bastante generales, dejando condicionado a futuros estudios la influencia de factores como son la microrrugosidad y el porcentaje de minerales minoritarios, sobre el CPA, o bien se centran en materiales sintéticos no usados como áridos. El poder relacionar de manera precisa estos parámetros petrográficos con el ensayo del CPA permitiría de una manera sencilla estimar el valor del CPA sin tener que realizar este ensayo, siempre caro y tedioso.

Por ello, se propone un estudio comparativo entre cinco tipos de áridos naturales y uno artificial, para lo que se ha determinado su valor del CPA y su microrrugosidad superficial y se han caracterizado petrográficamente, estableciéndose la relación entre estos tres parámetros y la influencia de la microestructura y la mineralogía sobre la microrrugosidad de los áridos, como un factor condicionante de la adherencia neumático-carretera al ser utilizados estos áridos en las mezclas bituminosas para capas de rodadura.

\section{INTRODUCTION}

The wearing course of carriageways contributes decisively to and determines the response of the road surface to the demands of safety, comfort, strength and impermeability. Regarding safety, the wearing course must have good skid-resistant properties, which depend on the road surface texture, and a minimum required roughness factor. In this regard, aggregate properties that will provide adequate levels of tyre-road adhesion must be considered in the bituminous mixtures used for wearing courses. Among the petrographic characteristics, mineralogy and microstructure are determinant factors (1-4). Some investigators have attempted to compare the results of technological tests (e.g., Polished Stone Value) with the microtexture $(5,6)$ and petrography of aggregates (7), but such studies have only focused on synthetic materials not commonly used as aggregates or merely provide an overall view, leaving the influence in the PSV test of factors such as the surface micro-roughness and the percentage of minor minerals for future studies. There is no doubt that precise estimation of the relationship between the PSV test value and a simpler method to estimate the extent to which aggregates resist polishing would enable performance of the PSV test, an expensive, tedious and time-consuming procedure, to be avoided.

The present work focuses on the relationship between the PSV test value and different petrographic and surface micro-roughness parameters. The study involved carrying out a comparative study of five natural aggregates and an artificial one in which the PSV test value and specific parameters used to typify surface micro-roughness and petrography were assessed. Regression analysis was used to identify those parameters, alternative to the PSV test that best defined resistance to polishing in aggregates. Finally, scanning electronic microscopy afforded guidelines for a better understanding of the role played by microstructure and mineralogy in aggregate micro-roughness, a determinant factor in tyre-road adhesion when aggregates are used in bituminous mixtures of wearing courses.

\section{MATERIALS AND WORKING METHODOLOGY}

Five samples of natural aggregates were considered in this study: namely, a limestone, a quartzite gravel, a quartzite, a hornfels and a dolerite, while only one sample of artificial aggregate was studied: an electric arc furnace slag.

The limestone, Tertiary in age, was from the region of Castilla-La Mancha in Spain. The quartzite gravel was from a Quaternary terrace of the Yeltes river (Salamanca, Spain). The quartzite was an Ordovician white quartzite 
Plantíos, al sur de Guijuelo (Salamanca), desarrollada en la aureola de metamorfismo de contacto entre la Fomación Monterrubio (pre-Ordovícico) y los granitos de Los SantosValdelacasa, mientras que la dolerita es la muestra usada, tal y como aconseja la norma, como patrón de los ensayos del CPA (8) y procede de Reino Unido. La escoria negra de acería procede de una fábrica ubicada en Santander.

De cada tipo de árido natural y artificial se fabricaron las correspondientes pastillas necesarias para realizar el ensayo de CPA de acuerdo con la norma UNE-EN 1097-8 (9).

De las pastillas ensayadas se realizaron láminas delgadas y transparentes-pulidas en secciones transversales a las mismas y se obtuvieron fragmentos centimétricos cortados de su parte central en el Servicio General de Preparación de rocas de la Universidad de Salamanca. Sobre las primeras se realizó el estudio petrográfico (que incluye la composición modal) y de la microrrugosidad. Para este último estudio se obtuvieron microfotografías con el microscopio óptico de polarización en aquellos fragmentos en los que se determinó la composición modal y mediante un programa de dibujo se contornearon las superficies de los fragmentos de árido en contacto con el abrasivo, sobre el cual se han determinado los parámetros normalmente utilizados para caracterizar la microrrugosidad superficial: ángulo de relieve $(\theta)$ de Delanne y Goyat (10) y los parámetros de Forster (11) como la altura del pico, el número de picos por unidad de longitud y el factor de forma. Igualmente, en las correspondientes láminas sobre las que se realizaron los perfiles, se midieron los tamaños de los granos y de los huecos, se determinó el porcentaje modal del material intersticial (matriz) en el caso de las rocas detríticas, así como el tamaño ocupado por las zonas alteradas en las rocas ígneas, mostrándose gráficamente bajo los perfiles todos los rangos de medida (Figura 1). La investigación sobre la microrrugosidad se ha completado con imágenes topográficas (electrones secundarios) de la superficie de los áridos, imágenes electrónicas (electrones retrodispersados) y microanálisis (Figuras 2 y 3), realizados sobre los fragmentos centrales y las láminas transparentes-pulidas en el Servicio General de Microscopía Electrónica de la Universidad de Oviedo.

En la escoria negra, debido a las dificultades planteadas en la identificación de las fases minerales al microscopio óptico, se realizaron además análisis de difracción de rayos $X$ sobre la muestra en polvo, en el Servicio General de Difracción de Rayos X de la Universidad de Salamanca. collected from the Barrios Formation in Leon. The hornfels was collected at the Los Plantíos quarry, close to the town of Guijuelo (Salamanca), this rock resulting from the contact metamorphism of the Los Santos-Valdelacasa granite in the metasediments of the Monterrubio Formation (pre-Ordovician). The dolerite was the standard type used in the PSV test (8) and came from the United Kingdom. The electric arc furnace slag was taken from a steelworks located in Santander (Spain).

The test specimens used in the PSV test (UNE-EN 1097-8 norm) (9) were made for the respective aggregate samples, both natural and artificial.

Thin and polished sections together with centimetre-sized sections were obtained at the University of Salamanca (Servicio General de Preparación de rocas), cutting the test specimens previously used in the PSV test transversally. The petrographic and surface micro-roughness studies were carried out using thin and polished sections. The surface micro-roughness was determined taking photos under a polarising optical microscope of the aggregate rims, which were contoured from a drawing program (Canvas(C)). Contours were then used to determine the parameters commonly used to characterize the surface micro-roughness: examples were the relief angle after Delanne and Goyat (10) and Forster's parameters (11): namely, the peak height, the peaks per unit length of profile, and the shape factor. Additionally, the grain size of minerals and vugs, the percentage of interstitial material (matrix) in detritic rocks, and the size of altered zones in igneous rocks were determined. These are shown graphically in Figure 1. Research into surface micro-roughness was completed with topographical images (secondary electrons) from the surface of the aggregates, electronic images (back-scattered electrons), and microanalysis (Figures 2 and 3) performed at the University of Oviedo (Servicio General de Microscopía Electrónica) from polished thin sections and centimetersized sections obtained from the test specimens.

Owing to the inherent complexity of identifying the mineral phases present in the electric arc furnace slag, study with the electronic microprobe was complemented using $X$-ray powder diffraction patterns, which were performed by the General X-Ray Diffraction Service of the University of Salamanca. 


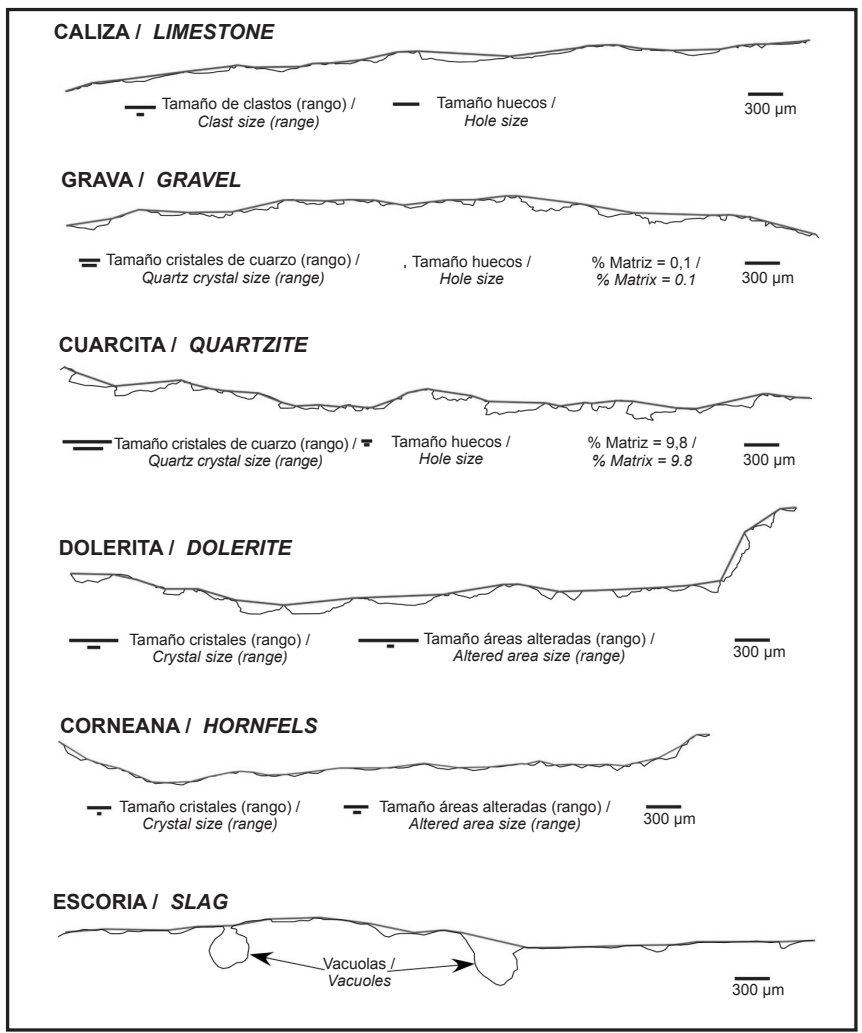

Figura 1. Geometría de los perfiles (líneas inferiores) seleccionados de los fragmentos centrales de los áridos. Se incluyen las envolventes para estimar el ángulo de relieve (líneas superiores), el rango de variación del tamaño de los granos y de los huecos rellenos de material intersticial (arcillas o micas) y el porcentaje modal del material intersticial (\% matriz).

Figure 1. Geometry of the selected transverse profiles (lower lines), also included are the envelopes to estimate the relief angle (upper lines). Variations in the size of grains and vugs filled by interstitial material (clays or micas) together with the modal composition of the interstitial material (\% matrix).

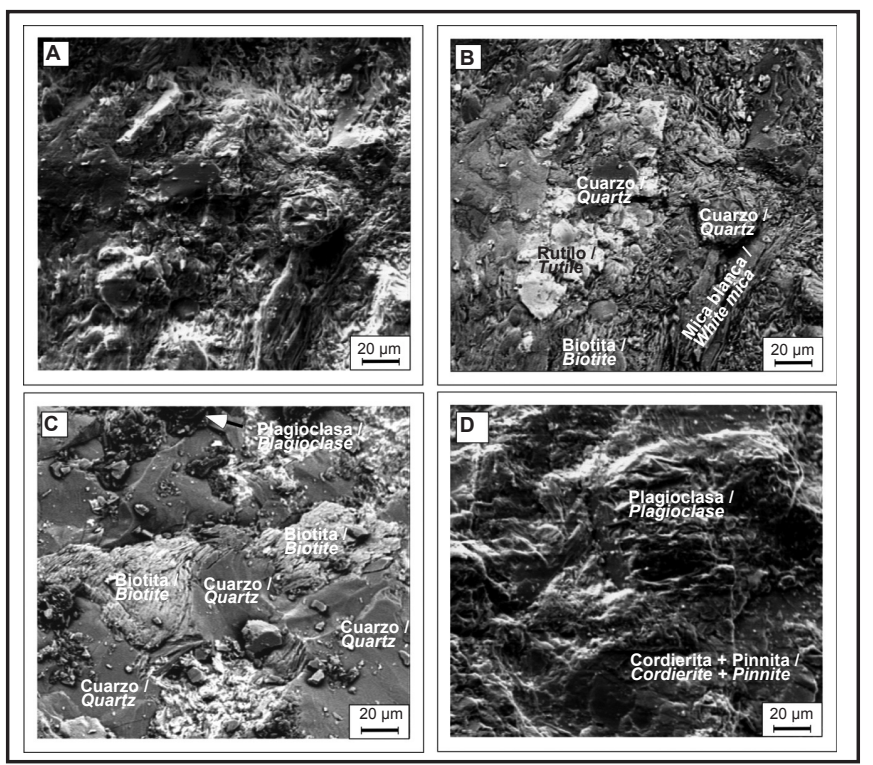

Figura 2. A y B) Estudio de la topografía y de la composición mineral del fragmento 1 de la corneana. La microfotografía A, con electrones secundarios, muestra una superficie poco pulida. B) Mismo motivo con electrones retrodispersados. Se incluye el nombre de los minerales determinados por microanálisis. C) Aspecto del fragmento 4 de la corneana observado con electrones retrodispersados, donde se observa la fractura concoidea del cuarzo. D) Microfotografía del fragmento 3 de la corneana mostrando un detalle de un cristal de plagioclasa con marcada exfoliación.

Figure 2. A and B) Study of the topography and mineral composition in fragment 1 of the hornfels. Microphotograph $A$ was acquired under secondary electrons and shows a scarcely polished surface. B) The same as A but with back-scattered electrons. The name of the minerals determined with microanalysis are also included. C) Typical quartz-conchoidal fracture in hornfels, fragment 4, observed under back-scattered electrons. D) Marked cleavage in a plagioclase crystal of the hornfels (fragment 3). 


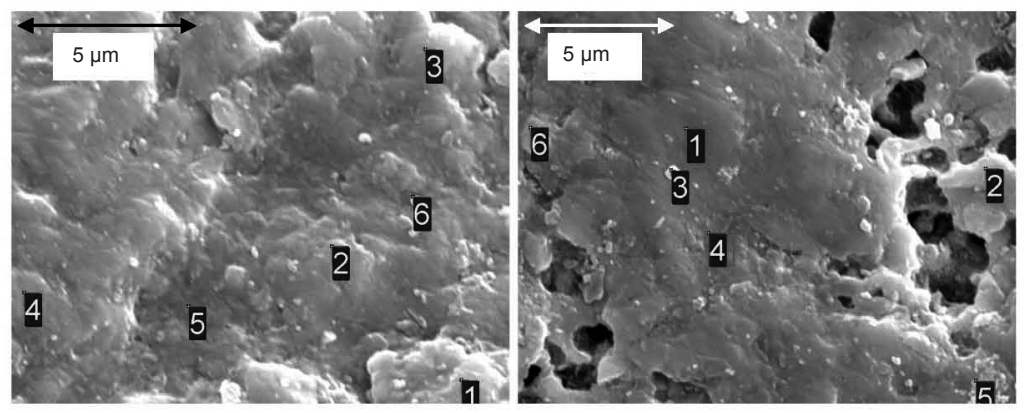

Figura 3. Estudio de la topografía de la muestra de escoria. Microfotografías tomadas del microscopio electrónico de barrido (electrones secundarios) con indicación de los puntos analizados. Izquierda: 1, 3 y 6 corresponden a wustita; 2 y 4 corresponden a magnesioferrita y/o jacobsita; 5 corresponde a siderita. Derecha: 1 y 3 corresponden a magnesioferrita y/o jacobsita; 2 es siderita; 4 es brownmillerita; 5 y 6 corresponden a wustita.

Figure 3. Study of topography in the furnace slag. Microphotographs were taken under a SEM (secondary electrons), including the points analyzed. Left: 1, 3 and 6 proved to be wüstite; 2 and 4 proved to be magnesioferrite and / or jacobsite; 5 proved to be siderite. Right: 1 and 3 were magnesioferrite and / or jacobsite; 2 was siderite; 4 was brownmillerite; 5 and 6 proved to be wüstite.

\section{RESULTADOS}

\subsection{Ensayos del coeficiente de pulimento acelerado (CPA)}

Los ensayos del CPA se han realizado de acuerdo con la norma UNE-EN 1097-8. Los resultados obtenidos se recogen en la Tabla 1.

\section{RESULTS}

\subsection{Polished stone value tests (PSV)}

The PSV tests for all the samples were performed foIlowing the UNE-EN 1097-8 norm. The results are shown in Table 1.

Tabla 1 / Table 1

Valores del CPA de las muestras estudiadas. PSV of the samples studied.

\begin{tabular}{|c|c|c|c|c|c|c|}
\hline \multicolumn{9}{|c|}{ Áridos naturales / Natural aggregates } & $\begin{array}{c}\text { Áridos artificiales I } \\
\text { Artificial aggregates }\end{array}$ \\
\hline & $\begin{array}{c}\text { Caliza I } \\
\text { Limestone }\end{array}$ & $\begin{array}{c}\text { Grava cuarcítica / } \\
\text { Quartzite gravel }\end{array}$ & $\begin{array}{c}\text { Cuarcita / } \\
\text { Quartzite }\end{array}$ & $\begin{array}{c}\text { Dolerita patrón I } \\
\text { Standard dolerite }\end{array}$ & $\begin{array}{c}\text { Corneana I } \\
\text { Hornfels }\end{array}$ & $\begin{array}{c}\text { Escoria negra / } \\
\text { Furnace slag }\end{array}$ \\
\hline CPA & 35 & 45 & 49 & 52.5 & 56 & 53 \\
\hline
\end{tabular}

\subsection{Estudio petrográfico}

1. Caliza. Presenta microestructura clástica, con clastos de tamaño comprendido entre 0,25 y 0,5 mm. En unos fragmentos predomina la matriz micrítica y en otros los clastos. Es prácticamente monominerálica, con un porcentaje de carbonatos superior del $99 \%$ en volumen. Siguiendo los criterios de Dunham (12) los fragmentos son de los tipos mudstones y wackestones.

2. Grava cuarcítica Desarrolla microestructura granoblástica, frecuentemente isogranular y en mosaico y su tamaño de grano oscila entre 0,1 y 0,25 mm. Frecuentemente muestra bordes suturados, que le confieren a la roca un fuerte grado de cohesión. En determinados fragmentos, los más areniscosos, la mica blanca y la

\subsection{Petrographic studies}

1. Limestone. This rock had a clastic texture, with clast sizes ranging between 0.25 and $0.5 \mathrm{~mm}$. The rock is a single-mineral material, the percentage of carbonates being higher than $99 \%$ in volume. In some fragments, there was a predominance of the micritic matrix, whereas in others clasts prevailed. The fragments were classified as mudstones and wackestones, after Dunham (12).

2. Quartzite gravel. This consisted of quartzite and sandstone fragments, the former being much more abundant. The quartzite fragments exhibited a granoblastic texture, frequently isogranular, with a grain size ranging between 0.1 and $0.25 \mathrm{~mm}$. In these fragments, the quartz grains usually showed suturated rims, 
clorita pueden llegar a ser constituyentes esenciales, mientras que la proporción de matriz de los términos más cuarcíticos es del orden de $0,1 \%$ en volumen.

3. Cuarcita. Con la misma textura y microestructura que la precedente, el tamaño de los clastos varía entre 0,25 y $1 \mathrm{~mm}$. Los contactos entre granos no se encuentran suturados, sino que son completos o cóncavo-convexos, lo que evidencia un grado de recristalización y de cohesión menor que el de las gravas cuarcíticas del Yeltes. Esta roca presenta una proporción de matriz más elevada que la grava cuarcítica, con valores del orden del $10 \%$ en volumen.

4. Dolerita. De microestructura ofítica e intersertal, su tamaño de grano varía entre 0,5 y $1 \mathrm{~mm}$. Consta de fragmentos compuestos por plagioclasa cálcica $(60 \%$ en volumen) y clinopiroxeno ( $27 \%$ en volumen) como minerales esenciales y cuarzo, ilmenita, apatito, pirrotina y calcopirita como accesorios. Una importante proporción de fragmentos corresponden a doleritas alteradas (i.e., diabasas según la norma UNE-EN 932-3) (13), constituidas por albita (56 a $67 \%$ en volumen), clorita (30\% en volumen), epidota, titanita, pumpellyita, prehnita, cuarzo, epidota, carbonatos, apatito y calcopirita (Tabla 2). providing high cohesion to the rock. The proportion of matrix was especially low ( $0.1 \%$ in vol.), in contrast to the fragments of sandstones, where white mica and chlorite were sometimes the major minerals.

3. Quartzite. The texture of the quartzite was the same as the above quartzite gravel fragments: namely granoblastic and isogranular. In contrast, grain size was slightly higher ( 0.25 to $1 \mathrm{~mm}$ ); the matrix content was higher (10\% vol.), and the contact between grains was concave-convex or complete, instead of suturated, providing evidence of a lower degree of recrystallisation and cohesion than those of the quartzite gravel from the Yeltes area.

4. Dolerite. The texture was ophitic and intersertal and the grain size ranged between 0.5 and $1 \mathrm{~mm}$. Fragments of dolerites sensu stricto consisting of calcic plagioclase (60\% in vol.) and clinopyroxene $(27 \%$ in vol.) as major minerals, and quartz, ilmenite, apatite, pyrrhotite and chalcopyrite as accessory minerals were not especially abundant. However, altered dolerite fragments (i.e., diabases according to the UNE-EN 923-3 norm) (13) consisting of albite (56 to $67 \%$ in vol.), chlorite (30\% in vol.), titanite, pumpellyite, prehnite, quartz, epidote, carbonates, apatite and chalcopyrite (Table 2) were fairly abundant.

Tabla 2 / Table 2

Composición modal de cada muestra de árido.

Modal composition of the aggregate samples studied.

\begin{tabular}{|c|c|c|c|c|c|c|c|c|c|c|c|c|c|c|c|}
\hline Mineral / Mineral & $\begin{array}{c}\text { Caliza / } \\
\text { Limestone }\end{array}$ & & ava cL & $\begin{array}{l}\text { rcític } \\
\text { grave }\end{array}$ & & & Luarcit & & & plerita & Dolerit & & & $\begin{array}{l}\text { ornean } \\
\text { Hornfe }\end{array}$ & \\
\hline Carbonatos / Carbonates & 99.8 & - & - & 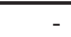 & - & - & - & - & - & 4.4 & & - & & & - \\
\hline Cuarzo / Quartz & - & 95.6 & 93.2 & 99.9 & 97.7 & 97 & 95.7 & 90.2 & 1 & - & 12.6 & - & 15.2 & 17.4 & 13.1 \\
\hline Matriz / Matrix & - & 4.4 & 6.8 & 0.1 & 2.39 & 3 & 4.3 & 9.8 & - & 62.2 & - & - & - & - & - \\
\hline Biotita / Biotite & - & - & - & - & - & - & - & - & - & - & - & - & 0.8 & 5.1 & 9.7 \\
\hline Clorita / Chlorite & - & - & - & - & - & - & - & - & 0.3 & 14.6 & 8 & 30.1 & 22.2 & 14.6 & 9.2 \\
\hline Mica blanca / White mica & - & - & - & - & - & - & - & - & - & - & - & - & 1.3 & & 1.1 \\
\hline $\begin{array}{l}\text { Plagiocl. Fresca / } \\
\text { Fresh plagiocla }\end{array}$ & - & - & - & - & - & - & - & - & 57.2 & - & 2.9 & 1.6 & 1.7 & 4.7 & 3.3 \\
\hline Plag alterada / Altered plag & - & - & - & - & - & - & - & - & - & 17.8 & 65.4 & 55.5 & 8.5 & 5.8 & 20.3 \\
\hline Clinopiroxeno / Clinopyroxene & - & - & - & - & - & - & - & - & 26.6 & - & - & - & & - & - \\
\hline Anfíbol / Amphibole & - & - & - & - & - & - & - & - & 2.6 & - & - & - & - & - & - \\
\hline Pinnita / Pinnite & - & - & - & - & - & - & - & - & - & - & - & - & 49.9 & 51.1 & 41.5 \\
\hline Opacos / Opaques & 0.2 & - & - & - & - & - & - & - & 7.6 & - & 1.4 & 3.5 & 0.2 & 0.9 & 1.7 \\
\hline Epidota / Epidote & - & - & - & - & - & - & - & - & - & - & 8 & 2 & - & - & - \\
\hline $\begin{array}{l}\text { Zoisita-Clinoz. I } \\
\text { Zoisite-Clinoz. }\end{array}$ & - & - & - & - & - & - & - & - & 0.7 & - & 1.1 & - & - & - & - \\
\hline Prehnita / Prehnite & - & - & - & - & - & - & - & - & - & 1 & 0.6 & 0.8 & - & - & - \\
\hline Pumpellyita / Pumpellyite & - & - & - & - & - & - & - & - & - & - & - & 6.6 & - & - & - \\
\hline Titanita / Titanite & - & - & - & - & - & - & - & - & 3.9 & - & - & -1 & - & - & - \\
\hline Apatito / Apatite & - & - & - & - & - & - & - & - & - & - & - & -1 & 0.2 & 0.4 & - \\
\hline
\end{tabular}

-Mineral ausente / Absent mineral. 
El Coeficiente de Pulimento Acelerado y su relación con parámetros petrográficos (contraste de dureza y composición modal) y la microrrugosidad... Polished Stone Value Test and its relationship with petrographic parameters (hardness contrast and modal composition) and surface micro-roughness...

5. Corneana. De microestructura bandeada y nodulosa, su tamaño de grano varía entre 0,25 y $1 \mathrm{~mm}$. Como en el caso anterior se han diferenciado fragmentos de roca fresca y otros, la mayoría, metasomatizados. Los primeros están constituidos por biotita, cuarzo, cordierita y plagioclasa como minerales esenciales y por pirrotina, apatito, turmalina, circón, mica blanca, pentlandita y fibrolita como accesorios. Los fragmentos metasomatizados tienen cordierita transformada en pinnita ( 41 a $51 \%$ en volumen), biotita ( 1 a $10 \%$ en volumen) en clorita (9 a $22 \%$ en volumen) y la plagioclasa cálcica ( 2 a $5 \%$ en volumen) actualmente descalcificada (6 a 20\% en volumen) (Tabla 2). El cuarzo es un constituyente mayoritario y varía entre el 13 y el $17 \%$ en volumen.

6. Escoria negra. Su estudio petrográfico permite observar el grado de porosidad de los distintos fragmentos de la escoria, presentando algunos una microestructura muy porosa, con numerosas vacuolas, de gran tamaño, observándose incluso en determinados puntos coalescencia de las mismas, en los que la porosidad es $>50 \%$ en volumen. Por el contario, otros fragmentos presentan vacuolas aisladas $y$, en general, de menor tamaño, con valores de porosidad en torno al 2,5\% en volumen (Figura 4). Estas escorias están compuestas fundamentalmente por wüstita $(\mathrm{FeO})$ y larnita $\left(\mathrm{Ca}_{2} \mathrm{SiO}_{4}\right)$. De forma accesoria presentan otros silicatos de $\mathrm{Ca}, \mathrm{Mg}$ y $\mathrm{Al}$, óxidos de $\mathrm{Fe}$, $\mathrm{Mg}$ y $\mathrm{Mn}$ y carbonatos de Fe y Ca.
5. Hornfels. This exhibited a banded and nodulose texture, and its grain size ranged between 0.25 and $1 \mathrm{~mm}$. As in the above dolerites, unaltered and metasomatized fragments were found, the latter being the most abundant. The unaltered fragments consisted of biotite, quartz, cordierite and plagioclase as major minerals, and pyrrhotite, apatite, turmaline, zircon, white mica, pentlandite and fibrolite as accessories. The metasomatized fragments comprised quartz (6 to $20 \%$ in vol.), cordierite completely transformed to pinnite (41 to $51 \%$ in vol.), biotite (1 to $10 \%$ in vol.), to a large extent transformed to chlorite (9 to $22 \%$ in vol.), and calcic plagioclase (2 to $5 \%$ in vol.), mainly transformed to a more sodic component (6 to $20 \%$ vol.) (Table 2).

6. Furnace slag. Two types of fragments were distinguished in terms of their porosity: those with scarce vacuoles and those with vacuole enrichment. In the latter, the porosity estimated was above $50 \%$ in volume and sometimes the vacuoles were combined, while the scarce-vacuole type exhibited a dramatic decrease in porosity (2.5\% in vol.) and in vacuole size (Figure 4). From a mineralogical point of view, the furnace slag contained wüstite ( $\mathrm{FeO})$ and larnite $\left(\mathrm{Ca}_{2} \mathrm{SiO}_{4}\right)$ as major minerals, and other silicates of $\mathrm{Ca}, \mathrm{Mg}$ and $\mathrm{Al}$, oxides of $\mathrm{Fe}, \mathrm{Mg}$ and $\mathrm{Mn}$ together with Fe and Ca carbonates as accessory minerals.

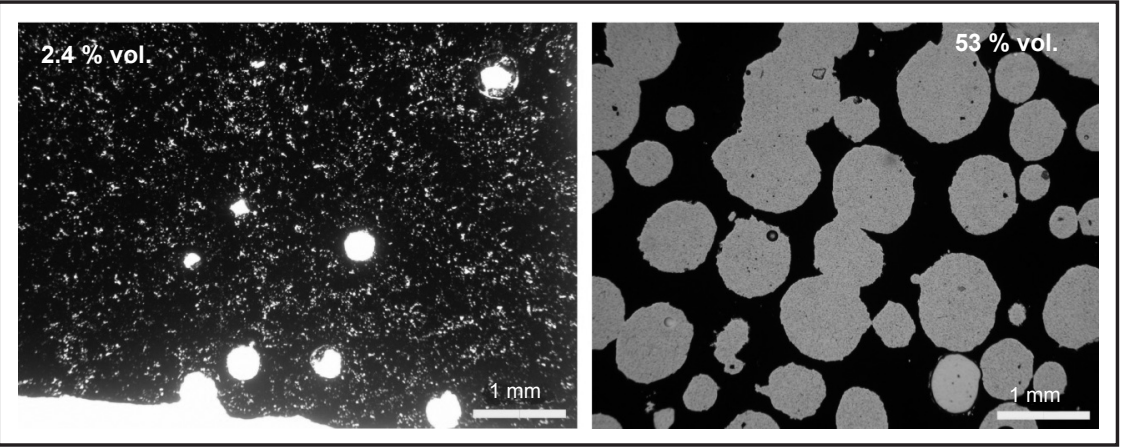

Figura 4. Disposición y porcentaje de vacuolas en dos fragmentos de escorias. Fotografías tomadas al microscopio petrográfico en luz transmitida y nícoles paralelos.

Figure 4. Disposition and percentage of vacuoles in two furnace-slag fragments. Images were taken under a petrographic microscope (transmitted and plane-polarized light).

\subsection{Estudio de la microrrugosidad superficial Perfiles transversales}

La geometría de los perfiles es variable en función del árido considerado, con perfiles escasamente sinuosos en la caliza y en algunos fragmentos de la grava y de la cuarcita y bastante más sinuosos en la dolerita. Los fragmentos de las cuarcitas y calizas que muestran perfiles más sinuosos

\subsection{Study of surface micro-roughness Transverse profiles}

The geometry of the transverse profiles studied varied considerably, depending on the lithology, since limestones and some fragments of the quartzite gravel and the quartzite itself showed a weak sinuosity, while irregular sections were especially evident in the dolerite. The 
son aquellos con un mayor tamaño de grano (200-450 $\mu \mathrm{m})$, mayor proporción de material intersticial $(10 \%)$ y mayor espaciado intergranular (75 $\mu \mathrm{m})$ (Figura 1).

Con respecto al ángulo de relieve, las muestras con mayores valores de este parámetro se encuentran en la dolerita y la escoria (Tabla 3). Con respecto a los parámetros de Forster (8), el factor de forma es bajo en la caliza y en orden ascendente continúa con la corneana, grava, cuarcita, dolerita y escoria (Tabla 3). Respecto al número de picos por unidad de medida, la muestra que ha presentado un menor número de picos ha sido la grava, seguido de la cuarcita, caliza, corneana y dolerita, la cual llega a casi 4 picos/mm frente a los 1,8 de la escoria (Tabla 3). former rocks (i.e., rocks with a single mineral) displayed the highest sinuosities in fragments with the largest grain sizes (200-450 $\mu \mathrm{m})$, the highest proportions of interstitial material (10\% in vol.), as well as the highest intergranular space $(75 \mu \mathrm{m})$ (Figura 1).

Regarding Foster's parameters (8), in the limestone the shape factor had the lowest value, which progressively increased in the hornfels, quartzite gravel, quartzite, dolerite and furnace slag, respectively. Similarly, the lithology with the lowest peaks per unit length of profile was the quartzite gravel, followed by the quartzite, limestone, hornfels and dolerite, the latter with a value up to 4 peaks $/ \mathrm{mm}$ as compared with 1.8 of the furnace slag (Table 3). Moreover, the lithotypes with the highest values of the relief angle were the dolerite and the furnace slag (Table 3).

Tabla 3 / Table 3

Parámetros utilizados y resultados obtenidos en la caracterización de la microrrugosidad superficial. Parameters used and results obtained in the characterization of surface micro-roughness.

\begin{tabular}{|c|c|c|c|c|c|c|}
\hline & $\begin{array}{c}\text { Caliza / } \\
\text { Limestone }\end{array}$ & $\begin{array}{c}\text { Grava / } \\
\text { Gravel }\end{array}$ & $\begin{array}{c}\text { Cuarcita / } \\
\text { Quartzite }\end{array}$ & $\begin{array}{c}\text { Dolerita / } \\
\text { Dolerite }\end{array}$ & $\begin{array}{c}\text { Corneana / } \\
\text { Hornfels }\end{array}$ & $\begin{array}{c}\text { Escoria / } \\
\text { Slag }\end{array}$ \\
\hline Ángulo de relieve $(\Theta)$ / Relief angle $(\Theta)$ & 6.1 & 10.4 & 8.8 & 15.1 & 10.7 & 13.3 \\
\hline $\begin{array}{c}\text { Altura/anchura pico }(\mathrm{h} / \mathrm{w}) / \\
\text { Height/wide peak }(\mathrm{h} / \mathrm{w})\end{array}$ & 0.21 & 0.31 & 0.31 & 0.33 & 0.24 & 0.38 \\
\hline Altura de pico $(\mu \mathrm{m}) /$ Peak height $(\mu \mathrm{m})$ & 24 & 53 & 44 & 43 & 41 & 109 \\
\hline Picos/mm / Peaks/mm & 3.6 & 3 & 3.5 & 3.9 & 3.8 & 1.8 \\
\hline
\end{tabular}

Los valores corresponden a la media aritmética de todos los valores de cada tipo litológico. / Values correspond to the average of all values of every rock type.

\subsection{Estudio mediante microscopía electrónica de barrido (MEB)}

\section{Áridos naturales}

1. Caliza. Las imágenes de electrones secundarios muestran a bajos aumentos (10-50 $\mu \mathrm{m})$ una baja rugosidad. Por el contrario, a elevados aumentos (a escala de 1-5 $\mu \mathrm{m}$ ) la roca presenta una microtextura secundaria en el sentido de Gutt y Nixon (5) condicionada por las características físicas de lo carbonatos y la abundancia de cristales de pequeño tamaño de grano (micrita).

2. Grava cuarcítica. Las imágenes de electrones secundarios de todos los fragmentos de esta litología muestran, a bajos aumentos (300 x), una topografía mucho más irregular que la muestra de caliza, destacando la existencia de superficies más o menos planas y otras con abundantes microrrugosidades. Las primeras son las típicas superficies de rotura concoidea que presentan los minerales de la sílice.

3. Cuarcita. La topografía de esta roca es, en cierto modo, similar a la que presenta la muestra de grava.

\subsection{Scanning electron microscopy study (SEM)}

\section{Natural aggregates}

1. Limestone. Secondary electron images at low magnification (10-50 $\mu \mathrm{m})$ revealed low surface micro-roughness. In contrast, the secondary microtexture in the sense of Gutt and Nixon's (5) definition was evident at high magnification (a scale of 1-5 $\mu \mathrm{m}$ ), probably due to the physical characteristics of carbonates and the abundance of small crystals (micrite).

2. Quartzite gravel. Secondary electron images of all the fragments unveiled a much more irregular topography than the limestone at low magnification (300x). At this magnification, the existence of almost flat surfaces was noteworthy, in contrast to others with abundant surface micro-roughness, the former corresponding to the typical conchoidal fracture surfaces of the silica minerals.

3. Quartzite. The topography of this rock was somewhat similar to that of the gravel sample. However, the 
El Coeficiente de Pulimento Acelerado y su relación con parámetros petrográficos (contraste de dureza y composición modal) y la microrrugosidad... Polished Stone Value Test and its relationship with petrographic parameters (hardness contrast and modal composition) and surface micro-roughness...

Sin embargo, los fragmentos con una mayor proporción en matriz presentan mayor microrrugosidad, lo que debería traducirse en valores mayores del CPA, como ya ha sido puesto de manifiesto en materiales silíceos (14).

4. Dolerita. La observación con electrones secundarios permite diferenciar en algunos fragmentos una microestructura secundaria muy marcada, es decir a escala de $1-5 \mu \mathrm{m}$ y, en otros, microestructuras primarias (10-50 $\mu \mathrm{m})$ muy patentes. Se considera que la gran abundancia de filosilicatos secundarios de pequeño tamaño son los responsables de esta microrrugosidad. Cuando aparecen cristales de mayor tamaño, pueden desarrollarse planos de exfoliación marcados que dan lugar a superficies bastante irregulares. Algunos autores (8) han atribuido el alto valor del CPA de esta roca a la mezcla de minerales de distinta dureza y otros (15) apuntan a la textura ofítico-diabásica como responsable del mismo.

5. Corneana. Las imágenes de electrones secundarios muestran una microestructura primaria $(10-50 \mu \mathrm{m})$ bastante marcada en todas las muestras. La secundaria $(1-5 \mu \mathrm{m})$ es más patente en unos fragmentos que en otros y está fuertemente condicionada por la presencia de la pinnita y de otros filosilicatos como biotita y/o clorita. Las imágenes combinadas de electrones retrodispersados y secundarios (Figura 3) confirman la existencia de zonas prominentes, constituidas por minerales de mayor dureza (cuarzo, plagioclasa cálcica y, a veces, minerales de titanio como rutilo), con valores de dureza superiores a 6, y otras zonas deprimidas formadas por minerales más blandos, fundamentalmente filosilicatos y pinnita, cuyos valores están por debajo de 3.

6. Dentro de los minerales con relieves positivos existe un claro contraste entre la morfología del cuarzo y de la plagioclasa (Figura 2). El primero muestra superficies curvas y bastante lisas (fractura concoidea) propiciadas por la carencia de planos de exfoliación, mientras que la plagioclasa presenta planos de exfoliación muy marcados, dando lugar a superficies planas y a veces poco espaciadas.

7. Igualmente, existen diferencias morfológicas entre los minerales de relieve negativo, ya que la pinnita, por su pequeño tamaño de grano, aparece en agregados microcristalinos con superficies de escasa rugosidad, por el contrario la mica blanca, la biotita y su equivalente alterado (biotita cloritizada) se presentan en cristales mejor desarrollados y frecuentemente en forma fascicular, conformando una superficie muy irregular, sobre todo a pequeña escala (Figura 2). fragments with a higher matrix content also exhibited greater surface micro-roughness, which should result in higher values of the PSV, as has already been shown for siliceous materials (14).

4. Dolerite. The observation of secondary electrons allowed us to distinguish some fragments with a marked secondary microstructure (scale of 1-5 $\mu \mathrm{m}$ ) and other fragments where primary microstructures (10-50 $\mu \mathrm{m})$ were evident. The abundance of small crystals of secondary phyllosilicates could have been the cause of this very rough microstructure. In larger crystals, cleavage planes were frequently differentiated, resulting in rather rough surfaces. Some authors have attributed the high PSV value of dolerites to the occurrence of minerals with different hardnesses (8), while the presence of an ophitic-diabasic texture has been also claimed as being responsible for this (15).

5. Hornfels. The secondary electron images revealed a primary microstructure $(10-50 \mu \mathrm{m})$, that was fairly pronounced in all samples. The secondary microstructure (1-5 $\mu \mathrm{m})$ was strongly influenced by the occurrence of pinnite and phyllosilicates, such as biotite and/or chlorite. The combination of back-scattered and secondary electron images (Figure 3) confirmed the existence of prominent areas, consisting of minerals of greater hardness (quartz, calcium plagioclase and occasionally Ti minerals, such as rutile) with hardness values higher than 6, and depressed regions with softer minerals (hardness < 3): namely phyllosilicates and pinnite.

6. Regarding the minerals that afforded a positive relief, there was a clear contrast between the morphology of quartz and plagioclase (Figure 2). The former had fairly smooth curved surfaces (conchoidal fracture) prompted by the lack of cleavage planes, while plagioclase displayed very marked cleavage planes, resulting in flat surfaces, sometimes with a reduced spacing.

7. Moreover, morphological differences between negative relief minerals were observed in terms of grain size, with surfaces of low roughness in the microcrystalline aggregates, namely pinnite, and highly irregular surfaces, particularly on a small scale (Figure 2), in large crystals of white mica, biotite and chloritised biotite. 


\section{Áridos artificiales}

Las microfotografías de electrones secundarios de los diferentes fragmentos de escoria negra muestran a bajos aumentos $(<100 \mathrm{x}$ ) una rugosidad bastante marcada debida a la presencia de las vacuolas anteriormente descritas, mientras que a elevados aumentos $(>10.000 \mathrm{x}$ ) muestra una superficie poco rugosa (Figura 3 ).

\section{DISCUSIÓN Y CONCLUSIONES}

En los áridos naturales el estudio de microscopía electrónica muestra que las rocas poliminerálicas presentan dominios de relieves positivos y negativos que favorecen un mayor grado de microrrugosidad que en las rocas monominerálicas, como la cuarcita o la caliza, lo que indica un control mineralógico en la microrrugosidad. No obstante, el hecho de que una roca sea poliminerálica no implica necesariamente una microrrugosidad acusada, como ha sido constatado en los fragmentos de dolerita y corneana sin alterar, donde la microrrugosidad no es muy manifiesta. Son los fragmentos obtenidos de estos áridos con una considerable proporción de minerales de alteración donde la microrrugosidad es más marcada. La particularidad de estos minerales de neoformación subyace en su menor dureza con respecto a la de sus precursores, así mientras la augita presenta una dureza de entre 5 y 6,5 en la escala de Mohs y la cordierita de 7 , la clorita tiene una dureza en torno a $2-2,5$ y la pinnita de 2 a 3 .

Igualmente, los perfiles transversales realizados en rocas de mineralogía escasamente variada, como la cuarcita y la grava cuarcítica, manifiestan un mayor grado de sinuosidad en los fragmentos con una mayor proporción de matriz de filosilicatos (dureza Mohs entre 2 y 3), confirmando que la presencia de minerales de diferente dureza y su proporción en la roca, son parámetros petrográficos que controlan fuertemente la microrrugosidad.

En las escorias negras, la geometría de los perfiles transversales varía principalmente en función del grado de porosidad. Los fragmentos menos porosos muestran menor sinuosidad, siendo su geometría similar a la de las rocas monominerálicas. En este sentido, hay que resaltar que el contraste de dureza entre sus componentes minerales mayoritarios wüstita (dureza $5-5,5$ ) y larnita (dureza 6) es muy parejo lo que también favorecería su baja sinuosidad. Por el contrario, en las muestras más porosas su sinuosidad es bastante elevada, ya que la presencia de una proporción elevada de vacuolas genera en la roca una elevada microrrugosidad que se renueva durante el proceso de desgaste. Todo ello sugiere que la microrrugosidad en la superficie de un árido está fuertemente condicionada

\section{Artificial aggregates}

At low magnification (below 100x), secondary electron microphotographs of different furnace slag fragments revealed a noticeable roughness in relation to the vacuoles described above. In contrast, at higher magnifications (around 10000x) the surface did not appear to be very rough (Figure 3).

\section{DISCUSSION AND CONCLUSIONS}

Scanning electron microscopy study of natural aggregates shows that polymineralic rocks have a sequence of domains with positive and negative reliefs, which are uncommon in single-mineral materials. This difference promotes a lower micro-roughness in monomineralic rocks, such as quartzite or limestone, which indicates a mineralogical control in micro-roughness. However, a polymineralic rock does not necessarily have a marked micro-roughness, since it was seen in unaltered fragments of the hornfels and the dolerite, where the micro-roughness was not evident. In contrast, those fragments of polymineralic rocks with a considerable proportion of altered minerals showed the most marked micro-roughness. It should be noted that the distinguishing characteristic of altered minerals relative to their precursors is the lower hardness of the former. Thus, for instance, the hardness of augite is 5 to 6.5 on the Mohs scale, whereas the newly formed mineral (chlorite) has a hardness ranging between 2 and 2.5. Similarly, in hornfels the hardness of cordierite is 7 , whereas pinnite has a hardness of 2 to 3.

Similarly, the transverse profiles of rocks with single-mineral materials, such as the quartzite and the quartzite gravel, exhibited higher degrees of sinuosity in the fragments with a greater proportion of phyllosilicates (Mohs hardness between 2 and 3), confirming that the proportion and the occurrence of minerals of different hardness are parameters that strongly control micro-roughness.

In the furnace slag, the micro-roughness was seen to depend strongly on the degree of porosity, with low micro-roughness in fragments with low porosity. In this case, the transverse profiles were quite similar to those of monomineralic rocks. In this regard, it should be noted that the contrast in hardness among the major mineral components in the furnace slag, that is, wüstite (hardness 5 to 5.5) and larnite (hardness 6), was very restricted, which also enhanced its low micro-roughness. In contrast, the high proportion of vacuoles of some fragments leads to high micro-roughness, which could readily be renewed during the wearing process. This suggests that surface micro-roughness in an aggregate is strongly controlled by the existence, in the aggregate itself, of components with 
El Coeficiente de Pulimento Acelerado y su relación con parámetros petrográficos (contraste de dureza y composición modal) y la microrrugosidad... Polished Stone Value Test and its relationship with petrographic parameters (hardness contrast and modal composition) and surface micro-roughness...

por la existencia, en dicho árido, de componentes con grados de dureza contrastados, como ya ha sido puesto de manifiesto $(16,17)$, a lo que también puede contribuir su microestructura (1).

Para el caso de las rocas ofíticas se ha establecido, por técnicas de regresión, una relación entre la composición mineralógica modal y el valor del CPA, siendo los minerales minoritarios (clorita, uralita, epidota, zeolitas, opacos, olivino, feldespato, moscovita y serpentina) los que parecen tener una especial incidencia en el CPA para este tipo de rocas (18). Sin embargo, podría ocurrir que en otro tipo de materiales los minerales minoritarios tuvieran el mismo grado de dureza que los componentes mayoritarios, lo que no produciría ningún efecto en la microrrugosidad ni en el valor del CPA, por lo que probablemente no se pueda extrapolar esta relación proporción mineral-CPA a todas las rocas. Por lo expuesto arriba parece evidente que si se quiere relacionar el CPA con la petrografía de los áridos han de involucrarse las diferencias de dureza entre los distintos minerales que constituyen la roca y su abundancia. Esto se pone de manifiesto con un parámetro que hemos denominado Contraste de Dureza Global $(\Delta \mathrm{H})$. Este se define según la expresión [1]: contrasting degrees of hardness, as previously proposed $(16,17)$.

Moreover, a relationship between the modal composition and the PSV test has been established by using linear regression analysis in ophitic rocks (18), where the proportion of minor minerals (chlorite, uralite, epidote, zeolites, opaques, olivine, feldspar, muscovite and serpentine) seems to have a particular impact on the PSV value of these rocks. However, in other rock types the minor minerals might have the same hardness as the essential ones, resulting in the absence of an effect on micro-roughness or the PSV value. Accordingly, the relationship between PSV and the minor mineral proportion probably cannot be extrapolated to all rocks. However, as mentioned above it is clear that the differences in hardness between minerals and the abundance of these are factors that must be involved in variations in micro-roughness and consequently in PSV values. This relationship can be seen from a parameter that we refer to as the Overall Hardness Contrast $(\Delta H)$ and is defined by the expression [1]:

$$
\Delta \mathrm{H}=\left[\text { ha } 100-(\text { ha Xa ) }]-\sum\right. \text { hi Xi }
$$

y de manera simplificada [2]:

Simplifying, one has [2]:

$$
\Delta \mathrm{H}=\text { ha } 100-\sum \mathrm{hj} \mathrm{Xj}
$$

Donde $\Delta \mathrm{H}$ es el contraste de dureza global, ha es la dureza de un mineral principal en la roca (e.g. cuarzo en cuarcitas y corneanas, calcita en calizas y plagioclasa en doleritas), 100 corresponde al porcentaje del mineral principal, Xa es la proporción real del mismo (\%), hi es la dureza del mineral i (excluyendo el mineral ha), Xi es la proporción modal del mineral i (\%), hj es la dureza del mineral $\mathrm{j}$ (incluyendo el mineral ha) y Xj es la proporción modal del mineral j.

A tenor de la expresión [1] en el contraste de dureza global se comparan la dureza y abundancia de un mineral de ese árido que se utiliza como patrón, generalmente abundante y de gran dureza, con respecto a esos mismos parámetros del resto de minerales que constituyen el árido (ver ejemplo práctico en la Tabla 4). Un elevado valor en $\Delta \mathrm{H}$ es indicativo de una importante proporción de minerales de menor dureza que el patrón, mientras que valores bajos indican una escasa proporción de minerales más blandos que el patrón. La elección del mineral patrón es lo más complicado a la hora de determinar $\Delta \mathrm{H}$, pero en el caso de cuarcitas, gravas cuarcíticas, $\mathrm{y}$ corneanas el cuarzo (dureza 7) es el mejor candidato ya que con otros se pueden obtener valores negativos where $\Delta H$ is the overall hardness contrast, ha is the hardness of a very abundant mineral in the rock (e.g., quartz in quartzites and hornfelses; calcite in limestones, and plagioclase in dolerites); 100 corresponds to the proportion of $100 \%$ of the very abundant mineral; Xa is the actual proportion of that mineral (\%); hi is the hardness of mineral $i$ (excluding mineral ha); $X i$ is the modal composition of the mineral $i(\%)$; hj is the hardness of mineral $j$ (including the mineral ha), and $X j$ is the modal composition of mineral $j$.

According to expression [1], in the $\Delta H$ the hardness and abundance of a mineral of an aggregate used as standard are compared with respect to the hardness and abundance of the rest of minerals constituting the aggregate (see practical example in Table 4). When the $\Delta H$ has a high value, this indicates a significant proportion of minerals with lower hardness than the standard, whereas a low value points to a low proportion of minerals softer than the standard. An important point in $\Delta H$ determination is the choice of the standard mineral, quartz (hardness 7) being the best candidate in quartzites, quartzite gravels and hornfelses, whereas plagioclase (hardness 6 to 7) and calcite (hardness 3) are the most suitable minerals in dolerites and limestones, respectively. In the case of the furnace 
que carecen de significado. Para el caso de la dolerita, la mejor elección ha resultado ser con la plagioclasa (dureza de 6 a 7) y para nuestra caliza muy pura sería con calcita (dureza 3). En la escoria, debido a la dificultad de estimar la proporción de sus componentes mayoritarios se ha tomado un valor promedio entre la dureza de wüstita y larnita (dureza 5,75 ) y una dureza de 0 para los poros. Un aspecto también muy importante es la representatividad de los fragmentos de roca a estudiar, ya que hemos podido constatar una relativa heterogeneidad (e.g., diferentes grados de alteración, diferentes proporciones de matriz, etc.) en todas las muestras. Por ello, es aconsejable estudiar varias láminas delgadas de cada muestra. slag, the assignment of the standard mineral was made considering the average value of the major components (wüstite and larnite; mean hardness of 5.75). A crucial feature in $\Delta H$ determination is the representativeness of the fragments studied, since in all samples we observed a relative heterogeneity, consisting of different degrees of alteration, different proportions of matrix or different grain sizes, among others. In order to avoid a lack of representativeness, it is recommended that several thin sections of each sample be studied.

Tabla 4 / Table 4

Cálculo del contraste de dureza global.

Calculations of the overall hardness contrast.

\begin{tabular}{|c|c|c|c|}
\hline Mineral / Mineral & Abund. Frg1 (\%) & Abund. Frg2 (\%) & Abund. Frg3 (\%) \\
\hline Cuarzo / Quartz & 97 & 95.7 & 90.2 \\
\hline Matriz / Matrix & 3 & 4.3 & 9.8 \\
\hline Total / Total & 100 & 100 & 655.9 \\
\hline Abund. $x$ Dureza / Hardness & 686.5 & 680.65 & $(100 \times 7)-655.9=44.1$ \\
\hline$\Delta$ Hq & $(100 \times 7)-686.5=13.5$ & $(100 \times 7)-680.65=19.35$ & \\
\hline$\Delta$ Hav & \multicolumn{2}{|c}{} \\
\hline
\end{tabular}

Abund.: Abundancia / Abundance.

Frg: fragmento / fragment.

* Principalmente filosilicatos / mainly phyllosilicates.

$\Delta \mathrm{Hq}$ : Contraste de dureza global con respecto al cuarzo / bulk hardness contrast relative to quartz;

$\Delta \mathrm{Hav}=$ Media del contraste de dureza global de todos los fragmentos / average bulk hardness contrast of all the fragments.

El Contraste de Dureza Global promedio calculado para todas las muestras presenta una excelente correlación con el CPA para una curva de regresión exponencial (Figura 5). La geometría de esta curva sugiere que el efecto de los minerales de menor dureza tiene su mayor incidencia en el CPA a bajas proporciones, ya que el CPA varía más acusadamente para los valores bajos del parámetro del Contraste de Dureza Global.

Por otra parte, los diagramas de variación que enfrentan el CPA con los parámetros normalmente utilizados para caracterizar la geometría de los perfiles transversales muestran siempre un grado de ajuste no demasiado bueno (Figura 6), por lo que su relación con el CPA no parece clara. Sin embargo, combinando algunos de estos parámetros (e.g., $\mathrm{n}^{0}$ pico/mm x altura de pico) la correlación mejora substancialmente. Se desprende, por consiguiente, que las variaciones del CPA con la microrrugosidad superficial o con la petrografía del árido, no son consecuencia de un solo parámetro sino de una combinación de ellos. El comportamiento general medio de la escorias negras es similar al de las rocas poliminerálicas (corneana y dolerita) (Figura 6), marcando la buena correlación entre la
The mean $\mathrm{OHC}$ calculated for all the fragments constituting each sample were correlated very well relative to the PSV, considering an exponential regression curve (Figure 5). It should be noted than the geometry of this curve shows a more marked variation in the PSV for the lowest values of the $\Delta H$, suggesting that the effect of the minerals with the lowest hardness in the PSV is more significant when the modal composition of these minerals is low.

Moreover, bivariate diagrams plotting the PSV against the parameters typically used to characterize the geometry of the transverse profiles always displayed a poor fit (Figure 6), indicating that the PSV was not clearly related to them. However, combining some of these parameters (e.g., numbers of peaks/mm x peak height) dramatically improved the match. Thus, the combination of parameters commonly used in the characterization of the surface micro-roughness (numbers of peaks/mm x peak height) or parameters used in the petrographic study (modal composition and mineral hardness) proved to be necessary for an accurate estimation of the PSV. The behaviour of the furnace slag, on average, was comparable to that of the polymineralic rocks (hornfelses and dolerites) (Figures 5 
microrrugosidad y el CPA, si bien en este caso las observaciones realizadas indican que es la porosidad asociada a las escorias la responsable principal de los elevados valores que las escorias presentan del CPA, similar al obtenido para rocas poliminerálicas con marcadas diferencias de dureza entre sus componentes minerales. Así, los valores de los fragmentos con bajos contenidos en vacuolas $(\theta=6,7)$ son comparables incluso a aquellos descritos para materiales geológicos casi monominerálicos. Por el contrario, los fragmentos con una mayor fracción gaseosa (de hasta un 53\% en volumen) presentan microporos que dan lugar a una superficie muy irregular y abrasiva y con ángulos de relieve que pueden llegar a ser equiparables a los de la dolerita retrogradada $(\theta=22,9)$. Cabe resaltar dos aspectos relevantes. Por un lado, los fragmentos de mayor fracción volátil presentan vacuolas de mayor tamaño $y$, por otro, suele haber coalescencia de vacuolas. Estas dos características son, "a priori", muy favorables para dar lugar a mayores ángulos de relieve y a una roca muy porosa capaz de generar superficies muy irregulares con el proceso de desgaste. and 6), with a good fit of the PSV with the surface microroughness (e.g., numbers of peaks/mm $x$ peak height or the relief angle) and with the $\Delta H$. However, the porosity of these types of material strongly controls the microroughness and the $\Delta H$. Accordingly, the fragments with low vacuole contents had $\mathrm{OHC}$ and relief angle values comparable to those of single-mineral rocks, whereas the fragments with high porosity (up to 53\% in volume) had micropores, leading to a rough surface with high relief angles and a high $\mathrm{OHC}$, which were comparable to those of the retrograded dolerite (see Table 3). It should be noted that the fragments with the highest volatile fractions had larger vacuoles, which were commonly coalesced. These features contribute to obtaining higher relief angles and a very porous rock capable of generating highly irregular surfaces as the wearing process progresses.

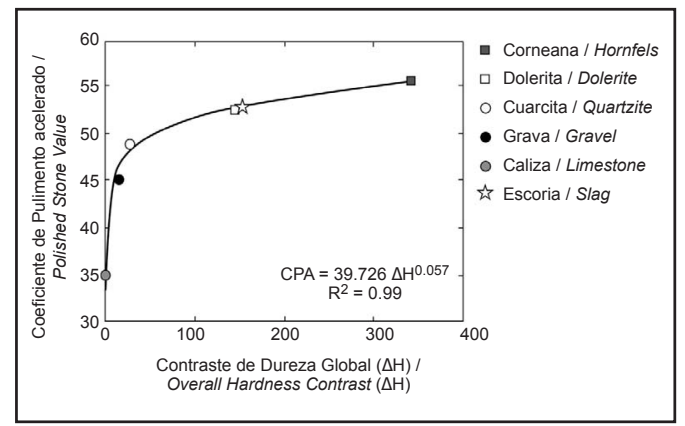

Figura 5. Contraste de Dureza Global frente a los valores del CPA para los áridos considerados. El Contraste de Dureza Global es un valor promedio calculado considerando todos los fragmentos de cada material.

Figure 5. Overall Hardness Contrast vs. the values of the PSV for the aggregates considered. The Overall Hardness Contrast is an average value calculated considering all fragments studied in every material.

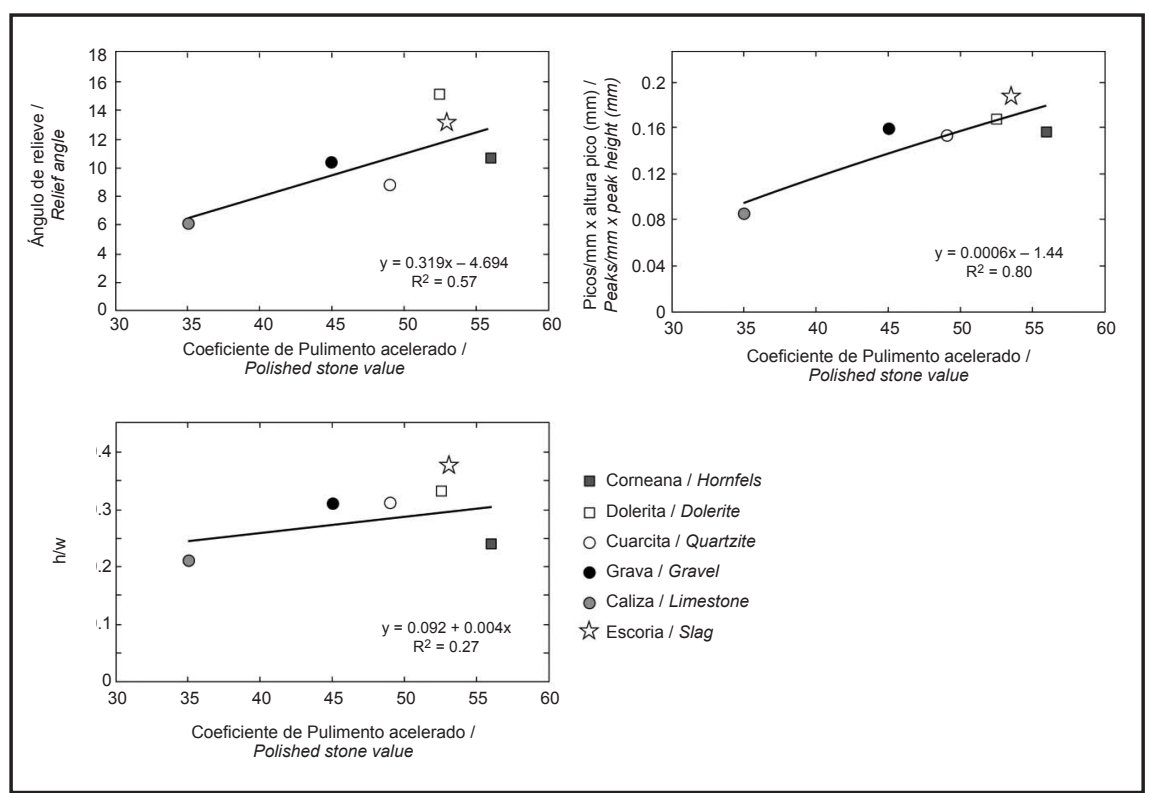

Figura 6. Gráficos mostrando la variación del CPA frente a diferentes parámetros que caracterizan la microrrugosidad superficial de los áridos. Figure 6. Plots showing the variation of PSV against different parameters used to characterize the surface micro-roughness in aggregates. 
En conclusión, el CPA está condicionado por el contraste de dureza de los componentes que conforman el árido, así como por la proporción de cada componente. Cuanto mayor es la diferencia en el grado de dureza de los componentes de la roca y mayor sea la proporción de minerales de menor dureza mayor es el CPA. La excelente correlación entre el CPA y el $\triangle \mathrm{H}$ significa que el contraste de dureza y proporción de los minerales que componen un árido son los factores petrográficos con una mayor incidencia en el ensayo del CPA, llegando a poder establecerse de manera bastante precisa el valor del CPA de un árido mediante la determinación del $\Delta \mathrm{H}$. Esta buena correlación indica que otros parámetros petrográficos, como el tamaño de grano y la dispersión de las fases mineralógicas, deben tener un menor peso a la hora de establecer el CPA de un árido a partir de estos parámetros. Para muestras originariamente porosas como las escorias de fundición o rocas volcánicas con abundante proporción de vacuolas, existe por un lado, un fuerte contraste de dureza entre los componentes que forman la matriz afanítica y las vacuolas y, por otro, la presencia de estos vacíos irregulares hacen renovar la microrrugosidad, por lo que a mayor proporción de vacuolas son también mayores los valores del CPA. Igualmente, la medida del pulimento de un árido puede también ser aceptablemente caracterizada mediante su microrrugosidad, la cual es fuertemente dependiente del número de picos/mm por la altura de cada uno de ellos.

\section{AGRADECIMIENTOS}

Este trabajo ha sido realizado en el marco del Proyecto de Investigación: Sostenibilidad y Seguridad en la Infraestructura Vial. Despliegue de nuevas tecnologías para la construcción, conservación y gestión sostenible y segura en las carreteras de Castilla y León (VIALCYL) cofinanciado por el Fondo Europeo de Desarrollo Regional y la Junta de Castilla y León. Se agradece a la empresa PAS Infraestructuras y Servicios S.L. el suministro de las muestras de áridos naturales y la realización de los ensayos del CPA. Los autores quieren agradecer los comentarios de dos revisores anónimos que ayudaron a mejorar la calidad del trabajo.
In conclusion, the PSV is influenced by the contrast of hardness of the components that constitute the aggregate and by the proportion of each component. The greater the difference in hardness between the rock components and the higher the proportion of minerals of lower hardness, the greater the PSV. The excellent correlation between the PSV and the $\triangle H$ indicates that the hardness contrast of minerals, together with the modal composition, are the petrographic factors with the greatest contribution to the PSV test; in fact, the PSV can be estimated by determining the $\Delta H$. Similarly, it seems likely that other petrographic parameters, such as grain size and the dispersion of mineral phases, are less relevant in the estimation of the PSV from petrographic studies. Several lines of evidence have suggested that in vuggy rocks (e.g., furnace slags and volcanic lavas) a higher abundance of vugs leads to higher PSV values, since, on the one hand, the hardness contrast between the components of the rock becomes more noticeable, and, on the other, microroughness is more readily renewed. Micro-roughness, assessed by the number of peaks / $\mathrm{mm}$ for the peak height, is another alternative method for estimating the PSV in aggregates, but is more tedious, time-consuming and less well correlated with the PSV than the $\Delta H$.

\section{ACKNOWLEDGEMENTS}

This work was carried out under the VIALCYL Research Project. We thank PAS Infraestructuras y Servicios S.L. for supplying the samples of natural aggregates and performing the PSV Test. The authors wish to thank the comments of two anonymous reviewers for their useful comments and suggestions, which contributed to improving the original version of the paper.

\section{BIBLIOGRAFÍA / BIBLIOGRAPHY}

(1) Carmona, F.; Prendes, N.: "Condicionamientos petrográficos de los áridos en la durabilidad e idoneidad de las capas de rodadura", $1^{\circ}$ Congreso Nacional de Áridos. Zaragoza 2006, pp. 251-260.

(2) Lucas, J.; Begou, P.A.: "Description de la macrotexture et de la microtexture", Bulletin de liaison des Laboratoires des Ponts et Chaussées, vol. 185 (1993), pp. 63-74.

(3) Ledee, V.; Delalande, G.; Dupont, P.: "Adhérence et granulats", Bulletin des Laboratoires des Ponts et Chaussées, vol. 255 (2005), pp. 91-116.

(4) Bustillo Revuelta, M, Calvo Sorando, J.P.; Fueyo Casado, L.: Rocas Industriales. Tipología, Aplicaciones en la construcción y empresas del Sector. Editorial Rocas y Minerales. (2001). 410 pp. 
El Coeficiente de Pulimento Acelerado y su relación con parámetros petrográficos (contraste de dureza y composición modal) y la microrrugosidad... Polished Stone Value Test and its relationship with petrographic parameters (hardness contrast and modal composition) and surface micro-roughness...

(5) Gutt, W.; Nixon, P.J.: "Studies of the texture of some roadstone materials by scanning electron microscopy", Journal of Materials Science, vol. 7 (1972), pp. 995-1002. http://dx.doi.org/10.1007/BF00550062

(6) Dupont, P.; Tourenq, C.: "Granulats et microrugusité", Bulletin de liaison des Laboratoires des Ponts et Chaussées, vol. 185 (1993), pp. 145-151.

(7) Romero, A.; Ávila, J. M.; Mota, M.I.: "Estudio inicial de la relación existente de los ensayos de CPA y desgaste de los ángeles con la petrografía, aplicada a los áridos silíceos en Extremadura". 10 Congreso Nacional de Áridos. Zaragoza 2006. pp. $277-281$.

(8) Smith, M. R. \& Collis, L.: Áridos. Áridos naturales y de machaqueo para la construcción (2a Edición). Geological Society, London, Special Publications, no 9 (1993). Versión española L. Suárez y M. Regueiro. Colegio Oficial de Geólogos de España (1994). 435 pp.

(9) Norma UNE-EN 1097-8: 2000. Ensayos para determinar las propiedades mecánicas y físicas de los áridos. Parte 8: Determinación del coeficiente de pulimento acelerado. Publicada en: Áridos para mezclas bituminosas y tratamientos superficiales de carreteras. AENOR.

(10) Delanne, Y.; Goyat, Y.: "Adherencia y seguridad vial". Carreteras, vol. 145 (2006), pp. 100-116.

(11) Forster, S.W.: Aggregate microtexture: profile measurement and related frictional levels. Informe de la Federal Highway Administration FHWA/RD-81/107. FHWA, U.S. Department of Transportation, Washington, D.C. (1981), 36 pp.

(12) Dunham, R.J.: "Classification of carbonate rocks according to depositional texture". En: W.E. Ham (ed.), Classification of carbonate rocks. Am. Assoc. Petrol. Geol. Mem.; vol. 1 (1962), pp. 108-121.

(13) Norma UNE-EN 932-3:1997. Ensayos para determinar las propiedades generales de los áridos. Parte 3: Procedimiento y terminología para la descripción petrográfica simplificada. Publicada en: Áridos para mezclas bituminosas y tratamientos superficiales de carreteras. AENOR.

(14) López-Moro, F.J.; Peinado Moreno, M.; Gonzalo Corral, J.C.; Franco González, P.; Rodríguez Alonso, M.D.; Fernández Calvo, C.; Payán de Tejada, F.J.: Recursos naturales de Castilla y León para su empleo en capas de rodadura. II Materiales silíceos canterables. Junta de Castilla y León. Consejería de Fomento (1999), 95 pp.

(15) Alonso Castro, E.; Franco González, M.P.; Gonzalo Corral, J.C.; Peinado Moreno, M.; Fernández, Calvo, C.; Payán de Tejada, F.J.: Estudio de los Recursos Naturales de Castilla y León para su Empleo en Capas de Rodadura. Junta de Castilla y León. Consejería de Fomento. Documentos Técnicos. (1994), 54 pp.

(16) Salinas Rodríguez, J.L.: "El pulimento y el desgaste de Los Ángeles en las areniscas utilizadas como áridos para carreteras". XXIX Congreso Luso-Español. Lisboa. Asoc. Portuguesa para el progreso de las ciencias (1970). Tomo II, pp. 59-73.

(17) Hartley, A.: "A review of the geological factors influencing the mechanical properties of road surface aggregates". Q.J. Engng. Geol, vol. 7 (1974), pp. 69-100. http://dx.doi.org/10.1144/GSL.QJEG.1974.007.01.05

(18) Fernández Maroto, G.; Suárez del Río, L.M.: "Coeficiente de Los Ángeles y de Pulimento Acelerado de áridos ofíticos de Cantabria: interpretación petrofísica". Mater Construcc.; vol. 54 (2004), pp. 53-63.. http://dx.doi.org/10.3989/mc.2004.v54.i275.247 